\title{
Cultural Problems in the Translation of frankenstein in Baghdad by Ahmed
}

\section{Sadaawy}

\author{
Submitted by \\ Master student of English language, Translation. \\ Falah Hussein Hanoon AL-sari \\ Department of English, Faculty of Arts, University of Tanta \\ Under the supervision of:
}

Prof. Mohamed Said Negm

Professor of Linguistics, Faculty of Arts, Tanta University

Prof. Abdul-Jawad El-Nady

Professor of English Literature, Faculty of Arts,

Tanta University

Dr. Heba Fawzy

Lecturer of Translation Studies, Faculty of Arts,

Tanta University 
r. 


\title{
المعوقات الثقافية في ترجمة رواية

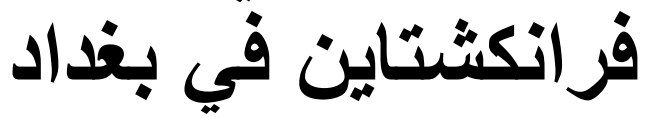

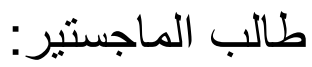 \\ فلاح حسين حنون الساري \\ قسم اللغة الانجليزية/تخصص ترجمة/كلية الاداب \\ جامعة طنطا
}

\section{تحت إثر اف}

الأستاذ الدكتور محمد سعيد نجم

أستاذ اللغويات، كلية الآداب، جامعة طنطا

الأستاذ الدكتور عبد الجواد النادي

أستاذ الأدب الإنجليزي، كلية الآداب، جامعة طنطا

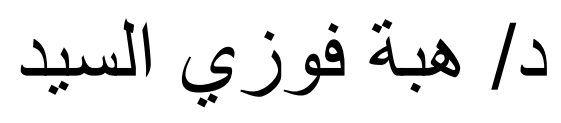




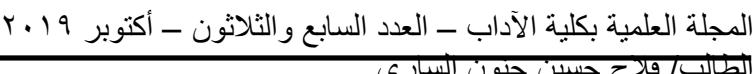

\section{Abstract}

This study attempts to analyze the strategies adopted by Jonathan Wright in his translation of Saadawi's novel, Frankenstein in Baghdad (2013), from a cultural approach. It claims that Wright's translation, in Newmark's terms, is "communicative" in nature, since it focuses much on the transfer of the verbal message of the source text. As this study argues, Wright's translation is mostly concerned with its target reader. In terms of culture, Wright employs many strategies according to whether the receiving culture has the same equivalents. Consequently, it will demonstrate the influence of such strategies on the process of translating Saadawi's novel. Wright's translation provides the cultural equivalent whenever possible.

However, since the Arabic and English languages belong to two distant cultures, cultural loss seems to be inevitable in translation, especially in translating literary works. Therefore, this study will analyze Wright's translation strategies employed to transfer the cultural markers, or the culture-specific items, in Saadawi's novel, which constitute its cultural identity. In so doing, this study will provide an 


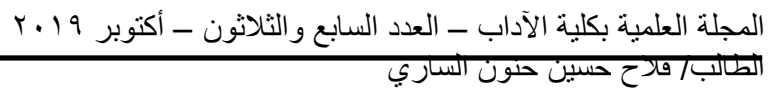

inventory of the cultural losses in Wright's translation. These losses will be categorized using Hanada AL-Masri's taxonomy of cultural losses according to the kind of change they cause to the source text.

\section{Introduction:}

What is in the locus, values, assumptions, beliefs, and preconceived notions that constitute the content of the meaning of a cultural translation is difficult or, sometimes, impossible to convey in translation. These blanks in the recipient culture, or lacunars, proceed to draw the attention of the linguists, as well as translation specialists.

\section{1}

Thus, lacunarity or hindrances in interpretation of sociocultural stereotypes is a challenging task stipulating reconsidering and rethinking means of translation.

The aim of the present work is to recognize specific parameters to determine lacunarity and to consider the ways of attaining precision and adequacy in translation of specific cultural concepts.

A cultural translation concept, merely disseminated and prevails in a language community in the form of implications completely or partially unintelligible to representatives of other cultures. This specific fragment of a national "world picture", called 


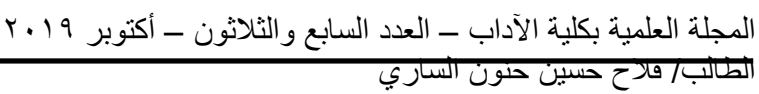

"lacuna", presents much difficulty in translation: hindrances of a sociocultural stereotype in interlingual translation is determined by lexical, cultural, historical, and social factors. Decomposing a stereotype pragmatic information into its sheer components could emphasize a particular contextual feature possible to render by means of translation language. Reproducing noticeable implications is of a special importance to have a pragmatic meaning of sociocultural stereotypes.

That is why cultural translation exists between the mindset of both the novelist and the translation on the scale translation hindrances and remedies. In this regards, the novelist, Ahmed Saadawi (born 1973), Iraqi , as poet, screenwriter and documentary filmmaker, was chosen in 2010 for Beirut 39, as one of the thirty-nine best Arab authors under the age of forty, and then in 2014 ascended to be the first Iraqi writer to win the prestigious International Prize for Arabic Fiction. Actually the prize is awarded to Frankenstein in Baghdad, as translated by Jonathan Wright, Briton and studying Arabic, Turkish and Islamic civilization at St John's College, Oxford to pave the way to his future ambition to delve into fertile lands.

\section{Analytical Classification of Cultural Losses}

The following is the study's inventory of the cultural losses in Wright's translation of Saadawi's novel, Frankenstein in Bagdad, according to Al-Masri's taxonomy.It is observed that many of the losses seem to 


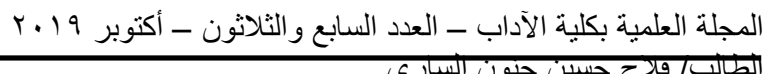

stem from adhering to the literal translation strategy in order to achieve the linguistic, or the formal equivalence, maintaining the communicative function of the source text rather than preserving its cultural identity. Moreover, many of the Iraqi vernacular and dialectic expressions, idioms and collocations are transferred into standard English.

Consequently, the target text seems direct and natural for target readers. In so doing, he tends to standardize and neutralize dialectic expressions and idiomatic collocations, however, at the expense of cultural equivalence.

\section{Explicit Losses}

This kind of cultural loss could be divided into two levels. The first is the "surface" level. The second is the "deep" level in which the target text fails to rendering the equivalent cultural significance and context of the source text. This seems to be because cultural-specific items, such as idioms and proverbs, are situation-based. That is, they must be translated in relation to the cultural context of the source text. As such, when "explicit" loss occurs, linguistic equivalence in the target text tends to be achieved at the expense of the cultural equivalence. 


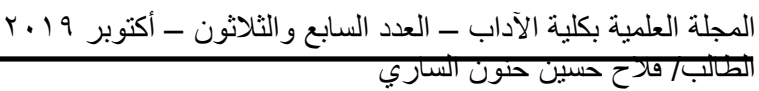

Explicit losses can be clearly seen in transferring idiomatic expressions including those which indicate social attitudes and practices. Explaining why translating idioms is challenging can be touched upon by looking at different definitions of what an idiom is. For Beekman and Callow, idioms are a sequence of "at least two words which cannot be understood literally and which function as a unit semantically" (in Larson 125). For Fernando and Flavell, transferring idioms in cross-cultural translation depends on the idiom stock in the receiving culture, as well as the level of aesthetic and rhetorical effects of the idioms as opposed to those in the target culture (85).

In order to translate idioms then, the translator should be accurate and "highly sensitive to the rhetorical nuances of the language" (85). Explicit losses can be illustrated in the following examples:

1. حدث الانفجار بعد دقيقتين من مغادرة باص الكئ الكيا (11) الذي ركبت فيه العجوز إيليشو أمن دانئ دانيال.

Which is translated as follows:

2. The explosion took place two minutes after Elishva, the old woman known 


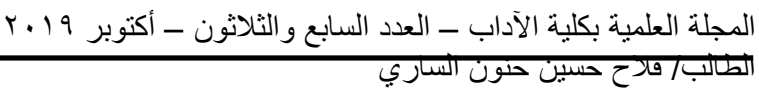

as umm Daniel, or Daniel's mother, boarded the bus. (11)

In the Arabic text, words that describe the nature of the environment in which events occur are of great significance. They help the readers depict the scene while reading.

Moreover, such words tend to be indicators of social, economic and cultural codes prevalent in this environment, place or setting. Here, Wright's translation overlooks the word "الكيا" which refers to the model of the bus. This word is significant in the Arabic text since it indicates the social status of the people and how the street looks like. Explicit cultural loss also appears in some of the strategies he applies, such as literal translation and transliteration. For example, the word "أم دانيال" literally translated as "Daniel's mother" which is used in the English culture to define the kind of relationship between two persons.

However, in the Arabic culture in general words such as "أبو", "بن" and "بن also used as titles or "Kunya" (Steed 111). The Islamic culture also adopted the notion of Kunya. Therefore, Muslim names "fall under five categories according to Islamic practice: Kunya, Ism, Nasab, Nisba and Laqab" (17). In order to solve this cultural constraint, Wright 


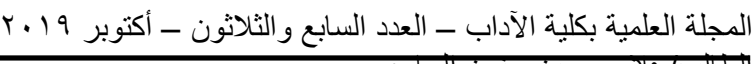

adds the phrase "known as" to refer to the notion of kunya. However, this cultural context seems to be totally absent for the target reader and thus resulting in reducing the aesthetic effect of the text upon the reader.

Culturally, such titles are used to address the elders in a decent and reverent way (Dickins \& Watson 101). This social significance is absent in the literal translation, "Daniel's mother", which only renders the linguistic equivalent of the Arabic, ignoring its social and therefore cultural reference. In other words, this explicit cultural loss overlooks the speaker's social attitude toward the old woman in the source context. As such, it seems that Wright often resorts to functional equivalence or literal translation when the linguistic equivalent exists but lacks the cultural reference of the source text.

As mentioned in the abstract, English and Arabic are distant cultures. Therefore, explicit cultural loss seems to almost always exist in translating Arabic-culture-oriented words, in general, and particularly, religiously rooted words. The following is an example

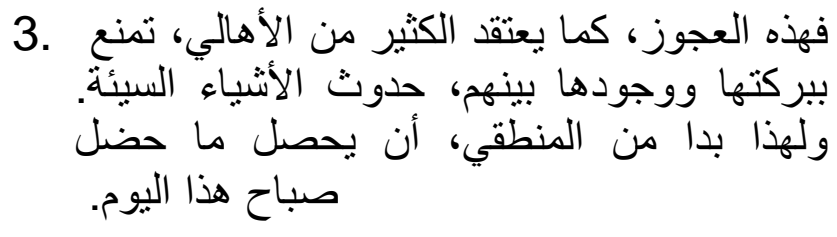


(11)

4. . . . and that's why the explosion happened-some of the locals believed that, with her spiritual powers, Elishva prevented bad things from happening when she was among them. (11)

As it seems, the text here reflects one of the common characteristics of the cultural and social codes. Such social attitudes shape the general cultural identity of the religiously-rooted Arabic community. This is obvious in translating the word "مبروكة" into "with her spiritual powers" as seen above. Sadaawy uses the word often throughout his novel, as well as its derivatives, such as "مبروكة".

According to Young, the Arabic culture has "attained a unique standing through its association with the liturgy and scripture of Islam" (99). In western culture, the Islamic concept of Baraka is often received as having "a supernatural power facilitating beneficent and miraculous acts" (43). Generally, this gift is given by God to those who are close to Him. However, the concept of Baraka is not exclusive to Islam. 


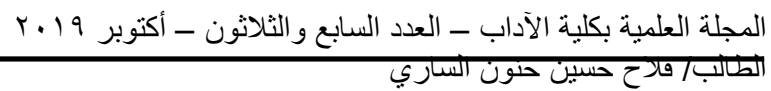

Heo also explains that this concept of baraka is common in all related religions. As he puts it:

Both Christians and Muslims . . . use the term baraka to signify the holy power of saints, prophets, and miracle-workers, and its special capacities to travel beyond ordinary space and time. (83)

However, unlike the conception of baraka in Christianity and Judaism, in which the word generally means sacred, Muslims believe that baraka "comes directly out of a relationship with Allah, rather than as a disciple of God in Christ" (Rheenen 202).

Therefore, in Arabic culture, this gift is also often associated with old people who are likely to have worshipped God much more than the young did. In short, although the concept of baraka exists in religions other than Islam, it has a different orientation in Islam and therefore different impact on individuals. In addition, explicit cultural loss here occurs on both the verbal and deep levels. In other words, neither the Arabic word "مبروكة" has a linguistic 


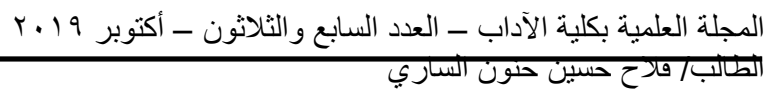

equivalent in the English language, nor the does it have the same cultural orientation as in Christianity and Judaism.

Explicit cultural loss is also apparent in the following excerpt. The source text contains expressions derived from the holy Quran which are impossible to transfer into English. The word, "بركة" is a derivative of the word" discussed above. Wright both transliterates the word and suggests a verbal equivalent which apparently differs in its connotative meanings from that of the English "spiritual power".

\section{Implicit Losses}

The implicit loss occurs if the translator fails to render the implicit cultural information hidden in the source text. It is highly culturally oriented. It is worth pointing out that some examples listed for analysis represent different types of cultural losses with varying degrees. For example, translating the Iraqi word istikana as teacup deprives the target reader of identifying the social practices within the source culture. Other examples represent neutralizing phrases that are considered idiomatic in the source language and culture. This leads to some loss of the 


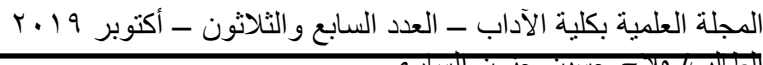

idiomatic character and therefore the cultural and social dimension of the source text.

In the following lines, the narrator comments on the social status of the old woman, Elishva. That is, some people perceive of the old woman as very close and connected to God and therefore she might be granted God's baraka. In the Arabic culture, this means that this person is supported by God, which means he or she can manage life difficulties easier than others who do not get supported by God. In the novel's context, Elishva being mabroka is perceived by neighbors with relation to preventing the explosions from happening in the place where she is. Therefore, people may stay close to her to be safe since she is protected by God. This is obvious in the following example:

$$
\begin{aligned}
& \text { هنالك شخصان هما الأكثر يقينا بان العجوز إيليشوا لا مجان }
\end{aligned}
$$

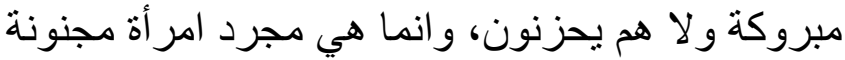

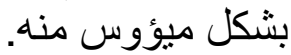

Which is translated as follows:

Two people were sure Elishva didn't have special powers or anything and was just a crazy old woman. (13) 


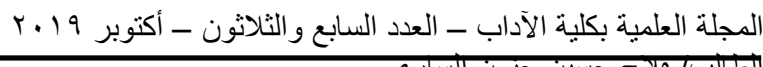

In this sense, this negative statement means that the old woman does not have any support from God. Therefore, bad things can happen to her like normal people. The Arabic phrase "وَلَا هُمَ يَحُزَنُونَ" affirms this negativity adding a sense of confidence in what they believe, which is their distrust of the woman being mabroka. This phrase is derived from the Quran. It comes from a Surah called Yunus, Aya 62, which says:

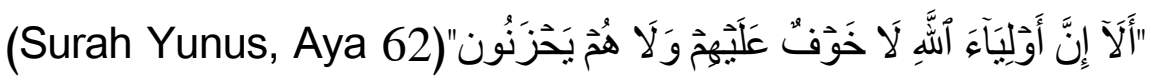

The Qur'anic ayah means that there is a specific kind of devoted believers, called أَوَلَيَاَءَ أَلَّهِ and supported by God. Therefore, no one should be worried about them, and they will never be grieved whatsoever. This ayah is translated by Mojama $\mathrm{Al}-$ malik Fahd as follows:

No doubt! Verily, the Auliyâ' of Allâh [i.e. those who believe in the Oneness of Allâh and fear Allâh much (abstain from all kinds of sins and evil deeds which he has forbidden), and love Allâh much (perform all kinds of good deeds which $\mathrm{He}$ has ordained)], no fear shall come upon them nor shall they grieve. 


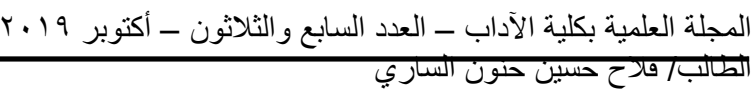

Wright translates this culturally specific phrase into "Elishva didn't have special powers or anything" (13). Thus, the Arabic phrase, which is seemingly a religious-based idiom, has lost all its cultural weight. Moreover, it has also lost its social reference or practice implicitly loaded in it, since the source phrase connotes a wide range of different emotions and thoughts including distrust and frustration. As such, Wright's translation successfully renders the communicative message, yet it seriously overlooks, or unable to deliver, the cultural and social implications behind it.

The following examples further illustrate the implicit cultural loss in translating idiomatic phrases, as well as culturally-rooted items including religion and social practices. For example, خلي عينك بعين الله is an Iraqi proverb which has many social and cultural implications according to the situation. In this context, this idiomatic expression means that one should be hopeful and trust God. This expression is definitely rooted in the Islamic culture. All Muslims are to undoubtedly believe in God's might and mercy in order for their payers to be fulfilled. 


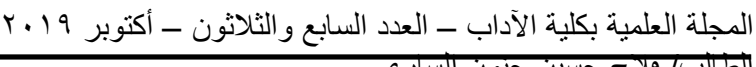

\section{Modified Losses}

This kind of cultural loss differs from other kinds in terms of its effect on the source text. It occurs when the target language and culture have equivalent idiomatic expressions similar to use of the source language and culture. As is the case in the implicit cultural loss, modified loss, as the term indicates, has its effects on the source text culturally rather than linguistically. In other words, it modifies the cultural context but preserves the linguistic and communicative aspects of the text. If other kinds stem from the distance from the Arabic and English cultures, cultural loss that results from modifying the cultural context of the source text actually represents a degree of sharing at least some similar perspectives toward the world.

This is mostly obvious in proverbs that refer to certain social and cultural values in a specific culture. However, other cultures also have their own way of referring to the same context. Translating collocations is a very illustrative example of modified cultural loss. For example, the phrase "power hungry" is perfectly translated into Arabic as "thirsty for power". Interestingly, the English uses the adjective 


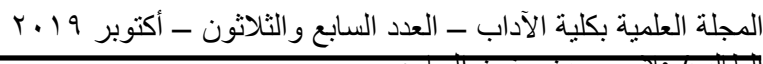

"hungry" figuratively which means wanting to eat, while the Arabic uses the adjective "thirsty" which means wanting to drink.

The following excerpts provide many examples in which cultural-specific items represent a real challenge in translation.

$$
\text { 1. 1الجثة يا عيني . . وين صارت؟ (بس) }
$$

And the corpse, for God's sake, what happened to that?

$$
\begin{aligned}
& \text { 2. فأين هو جسده الذي ينبغي أن يعود إليه كي يغدو }
\end{aligned}
$$

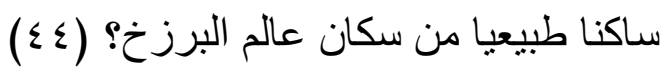

Where was the body to which it should return in order to take its place among those who live in a state of limbo? YV

In these examples, Wright neutralizes the Arabic cultural-specific items through using standard style and vocabulary. In other words, he resorts to The English language the cultural equivalents. Therefore, Wright replaces these cultural expressions with similar cultural expressions in English. The Arabic phrase "ياعيني" is translated into "for God's sake" while "عالم البرزخ" is transferred as "a state of limbo". Obviously, the English 


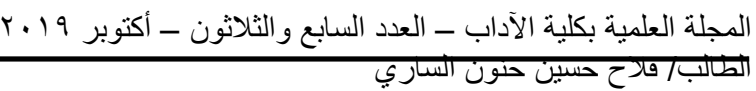

expressions fail to convey both the linguistic and cultural information implied by the Arabic expressions. However, Wright seems much more interested in situating the target readers within their own cultural context. According to Longman dictionary, the phrase "for God's sake" is a spoken expression used to emphasize something said while being annoyed.

According to these definitions, the Arabic and English expressions only share the potentiality of offense in some specific situations. Within the Arabic cultural context, if someone responds to someone else's speech saying "باعيني" could be offensive since its meanings vary to include not believing, sarcastic attitude or showing sympathy, depending on the speaker's tone. However, the English expression does different functions. In addition, the Arabic phrase "عالم "البرزخ "is a religiously rooted expression that refers to a state after death and before the Judgment Day (Yawm AlQiyamah). However, the English translation "a state of limbo" fails to convey any of this cultural information. This English phrase, according to the online Collins Dictionary, does not have any of these religious connotations: 


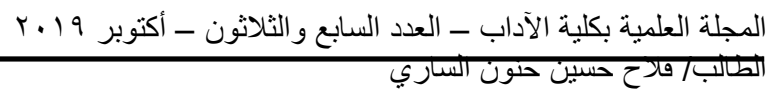

If you say that someone or something is in limbo, you mean that they are in a situation where they seem to be caught between two stages and it is unclear what will happen next. (online)

\section{Complete Losses}

This kind of cultural loss occurs when the target language does not have the cultural equivalent. Additionally, translating the cultural expression linguistically will fail to preserve any cultural information. It can only do the communicative function of the text. Therefore, many translators tend to omit such cultural expressions or figurative forms. The following phrase illustrates that some idiomatic expressions seem to be untranslatable:

$$
\text { و الله يهني سعيد بسعيدة (Y } 9 \text { (9) }
$$

Which is translated as thus:

$$
\text { ... may they live happily ever. (23) }
$$

In Arabic culture, this saying simply means wishing good luck for newly-wed couples, as well as being the perfect choice for each other.The folkloric story concerning 
the emergence of this saying is not of much importance here. However, even if the Arab reader does not know about it, he or she can grasp the message of the collocational phrase easily. For a target reader, it would be impossible to grasp such a meaning. Here, Wright prefers to translate the message, rather than providing a cultural equivalent.

Similarly, in the following excerpt, the narrator uses figurative language, which is religiously oriented, in order to express how easily Faraj could die. In religious literature, the phrase "الرفيق الأعلى" refers to Heaven, where it is believed that all souls get back to their creator after death. However, Wright translates the phrase literally capitalizing both words as if these words refer to a definite figure. However, many interpreters argue that this phrase does not refer to Allah. However, it may refer to Heaven, Al-Janna, or prophets living in Heavens.

مسكين . . لم يكن بحاجة إلا لدفعة صغيرة لكي يلتحق بالرفيق الأعلى. (r (9)

Poor man! It only took a little push for him to meet the Supreme Comrade." He spoke with 


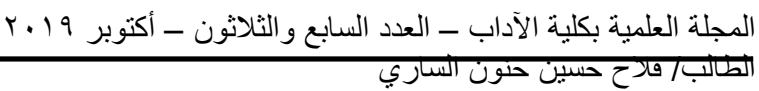

a touch of sarcasm, stretching out the word

"comrade" with a wry smile. (or)

As obvious, wright's literal translation causes a complete cultural loss since the translation does not provide an agreed-upon verbal sign, nor succeed in transferring the cultural information delivered by the source text. In the following example, complete cultural loss occurs due to the inevitable loss of the word play in the Arabic expression, which is based on using the same adjective "خفيف" for two different meanings.

اي ـ ـ ميخالف . . ظريف لطيف خفيف . . . شاي خفيف هها. (97 (1)

Yeah. Never mind. Nice, pleasant, funny. That tea story! (107)

As obvious, Wright uses the adjective "funny" to translate the first Arabic word "خفيف". "funny" represents a cultural and linguistic equivalent for the Arabic collocational phrase that describes persons who are funny. However, the second time, Wright conveys the meaning intended rather than collocational meaning or literal meaning. According to the narration, Wright uses the phrase "That tea story" to refer to a previous situation between Mahmoud and 


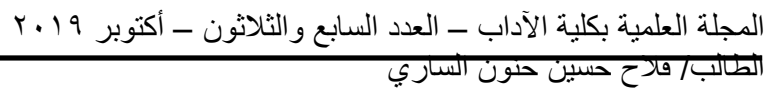

Brigadier Soror, in which the Brigadier talks about the tea being light and made of a mixture of herbs. In being light, not dark, the served tea by the Brigadier is supposed to make Mahmoud, literally, "light" also.

In other words, the Brigadier is implying for Mahmoud that he should be as light as the served tea and confess whatever the Brigadier asks for. However, in the English translation, this word play is gone since Wright uses different word forms for the same Arabic word in order to fulfil the communicative function of the source text. The analogy between the description of the served tea and what the Brigadier wants Mahmoud to be like is also lost in translation. Unfortunately, the cultural information implied by this figurative language is seemingly impossible to transfer.

Complete loss then seems to be inevitable. The target language lacks the cultural equivalent and what literal translation can do best is just to preserve the intended meaning. This is simply because each language has its culture-specific items that do not exist correspondingly in other language. Besides, cultural loss in cultural translation is largely dependent on factors such as religion, geography, 


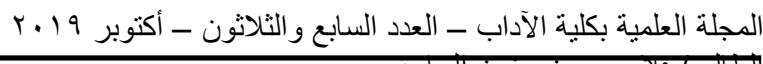

and social class, which are some of the constituents of culture. The following examples are a case in point:

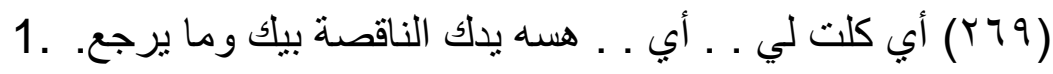
Yes, you told me, yes. Now you'll see how he tricks you.

2. راح يلعب بذيله . . لا مؤتمر ولا هم يحزنون. (T9 (Y)

He's gone there to play around. There is no conference. $(1 \mathrm{TH})$

In these examples, their collocational meaning cannot be grasped by conveying the literal meaning of the single words that constitute them. All these collocational expressions are charged with cultural information through figurative language using similes, analogies and proverbs with their social attitudes including the speaker's sarcastic tone. In the first example, the Iraqi collocational phrase " يدك is transferred only linguistically. However, in translation, it has lost its dialectical characteristic. Although Wright translates the message beyond this phrase, his translation succeeds in conveying only the intended meaning, rather than the dialectic, aesthetic and stylistic characteristics.

The second example contains two collocational phrases or idioms. The first is "راح يلعب بذيله" which is 


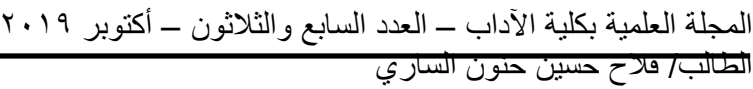

neutralized as "play around". Obviously, Wright chooses to render the intended meaning rather than providing culturally idiomatic equivalent. The second is "و لا هم يحزنون" which has been analyzed in a similar context before. This idiomatic expression, whose roots can be traced back to religious literature, indicates the speaker's social attitude, among many other things. In other words, the speaker's sarcastic voice is neutralized as "there is no conference" which is a direct translation of the meaning intended by the idiomatic phrase. Neutralizing the text deprives the target text from the cultural load within the source text. The target text has therefore lost a great deal of its aesthetic and rhetoric weight. As such, this study conceives of Wright's translation as one that preferred a comfort zone in dealing with the cultural and dialectic context of Sadaawy's novel.

\section{Conclusion}

The aim of this paper has been to discuss and analyze Wright's translation of Saadawi's novel, Frankenstein in Baghdad, from a cultural perspective. In cultural translation, culture "norms", in Hanada Al-masri's norms. Cultural translation is then seen as governed by 


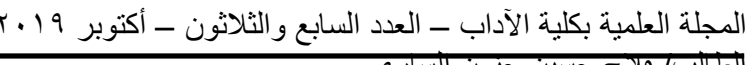

such cultural norms, which are specific to each single culture. They affect every aspect of the process of translation starting even from the choice of the work to be translated. According to Al-masri, in cultural translation, the translator then becomes a mediator between two cultures. As such, the process of translation is immersed in the cultural setting of both the translator and the text being translated.

These issues have been discussed in terms of the cultural losses in Wight's translation, as well as the varying strategies he has applied. From literal translation to communicative translation, Wright's translation inevitably suffers cultural losses categorized as explicit, implicit, modified and complete in Hanada Al-Masri's taxonomy. It has been shown that wright's translation is mostly communicative according to Newmark's opposition between communicative and semantic translations. Therefore, this paper has shown that wright's translation is mostly readercentered. It is much more concerned with providing the communicative and verbal equivalents rather than sticking to the cultural equivalence. 


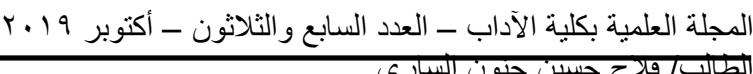

The paper has provided a detailed inventory of the cultural losses that have occurred in the translation of Saadawy's novel, Frankenstein in Baghdad. It has shown how Wright's choices and strategies in translating culturally specific items, both within the Iraqi culture, as well as the Arabic culture, have affected the overall product of translation. This research follows many cultural translation theorists that argue that cross-culture translation inevitably results in cultural loss, especially when dealing with two distant cultures. Therefore, this paper has demonstrated how Wright's strategies lead to these cultural losses which affect the reception of the translated text, as well as the cultural identity of the source text.Wright's resorting to communicative translation, whenever a cultural equivalent does not exist, is much a way to maintain at least the linguistic, verbal and communicative aspects of the source text.

\section{Works cited}

Dickens, James, and Janet C. E. Watson. Standard Arabic: An Advanced Course: Cambridge University Press, 1999.

Fernando, Chitra, and Roger Flavell. On Idiom: Critical

Views and Perspectives. Univ, 1981. 


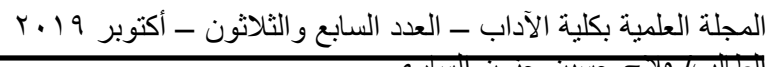

“For God's Sake for Goodness Sake for Heaven's Sake Definition and Meaning: Collins English Dictionary." For God's Sake for Goodness Sake for Heaven's Sake Definition and Meaning | Collins English Dictionary, HarperCollins Publishers Ltd, https://www.collinsdictionary.com/dictionary/english/fo r-gods-sake.

Heo, Angie. The Political Lives of Saints: Christian-muslim Mediation in Egypt. 2019.

Larson, Mildred L. Meaning-based Translation: A Guide to Cross-Language Equivalence. Univ. Press of America, 1998.

Minkov, Michael, and Geert Hofstede. Cross-cultural Analysis: The Science and Art of Comparing the World's Modern Societies and Their Cultures. SAGE, 2013.

Steed, Brian L. Bees and Spiders: Applied Cultural Awareness and the Art of Cross-Cultural Influence. 2014.

Van, Rheenen G. Communicating Christ in Animistic Contexts. William Carey Publishing, 2013. 


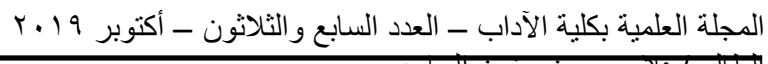

Young, Crawford. The Politics of Cultural Pluralism. The

University of Wisconsin Press, 1979.

“ ترجمة معاني سورة يونس - الترجمة الإنجليزية ـ هلالي-خان." موسو عة القرآن الكريم , أرجنة معاني

https://quranenc.com/ar/browse/english_hilali_khan/1 